\title{
A Broad-Spectrum, Catalytic Amidation of Sulfonyl Fluorides and Fluorosulfates
}

\author{
Mingjie Wei, ${ }^{\neq[a]}$ Dacheng Liang, ${ }^{\ddagger[a]}$ Xiaohui Cao, ${ }^{f[b]}$ Wenjun Luo, ${ }^{[a]}$ Guojian Ma, ${ }^{[a]}$ Zeyuan Liu, ${ }^{[a]}$ \\ and Le $\mathrm{Li}^{\star[a]}$
}

\begin{abstract}
A broad-spectrum, catalytic method has been developed for the synthesis of sulfonamides and sulfamates. With the activation by the combination of a catalytic amount of 1hydroxybenzotriazole (HOBt) and silicon additives, amidations of sulfonyl fluorides and fluorosulfates proceeded smoothly and excellent yields were generally obtained (87\%-99\%). Noticeably, this protocol is particularly efficient for sterically hindered substrates. Catalyst loading is generally low and only $0.02 \mathrm{~mol} \%$ of catalyst is required for the multidecagram-scale synthesis of an amantadine derivative. In addition, the potential of this method in medicinal chemistry has been demonstrated by the synthesis of the marketed drug Fedratinib via a key intermediate sulfonyl fluoride 13. Since a large number of amines are commercially available, this route provides a facile entry to access Fedratinib analogues for biological screening.
\end{abstract}

\section{Introduction}

Sulfonamide has been marked as one of privileged structural motifs in pharmaceutical and agrochemical industries. $^{[1]}$ Many commercial therapeutic agents and herbicides contain a sulfonamide functional group (Figure 1). Although a number of modern methods have been developed such as oxidative $\mathrm{N}-\mathrm{S}$ bond formation, ${ }^{\left[{ }^{[2]}\right.}$ metal-catalyzed cross coupling, ${ }^{[3]} \mathrm{N}$-functionalization of primary sulfonamides, ${ }^{[4]} \mathrm{C}-\mathrm{H}$ amination, ${ }^{[5]}$ and other miscellaneous methods, ${ }^{[6]}$ traditional amidation of sulfonyl chlorides with amines remained one of the most general methods to prepare sulfonamides in terms of cost and availability of raw materials. However, sulfonyl chloride chemistry faces inevitable challenges due to the electrophilic and oxidative nature of sulfonyl chlorides. Indeed, reactions of sulfonyl chlorides with amines are compromised by multiple undesired pathways such as non-selective sulfonylation, hydrolysis, reduction of $\mathrm{S}(\mathrm{VI})$, and chlorination. ${ }^{[7]}$

Sulfonyl fluorides ${ }^{[8,9 f]}$ have been regarded as an attractive surrogate for sulfonyl chlorides due to their superior stability and tunable reactivity. To emphasize such unique reactivity involving $\mathrm{S}(\mathrm{VI})-\mathrm{F}$ bonds, Sharpless recently coined the term "sulfur(VI) fluoride exchange (SuFEx) chemistry". ${ }^{[9]}$ Meanwhile, sulfonyl fluorides, fluorosulfates, ${ }^{[9, f]}$ and other compounds ${ }^{[10]}$ with $\mathrm{S}(\mathrm{VI})-\mathrm{F}$ bonds, have gained increasing attention on drug

[a] M. Wei,‡ Dr. D. Liang, † W. Luo, G. Ma, Z. Liu, Prof. L. Li PCFM Lab and GDHPRC Lab, School of Chemistry, Sun Yat-sen University, Guangzhou 510275, P. R. China; E-mail: lile26@mail.sysu.edu.cn

[b] Prof. X. Caoł

School of Pharmacy, Guangdong Pharmaceutical University, Guangzhou 510006, P. R. China

[ ] These authors contributed equally.

Supporting information for this article is given via a link at the end of the document. discovery, ${ }^{[11]}$ chemical biology,${ }^{[12]}$ and material science.${ }^{[9 e, 13]}$

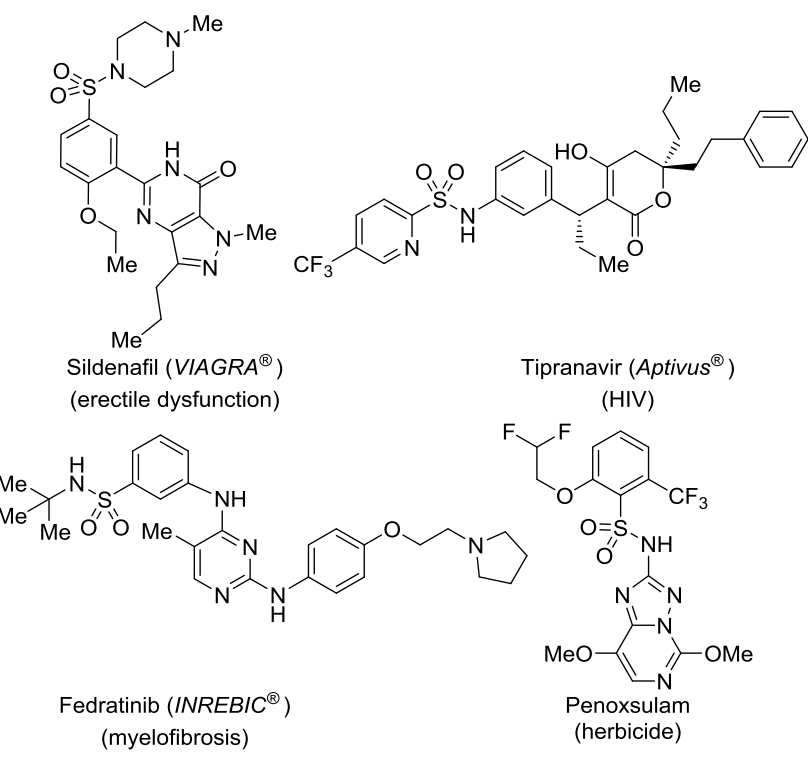

Figure 1. Representative sulfonamide molecules.

In the context of synthetic chemistry, highly efficient protocols developed by Gembus ${ }^{[14]}$ and Sharpless ${ }^{[9 e, f]}$ have been exceptionally successful in connecting O-nucleophiles with $\mathrm{S}(\mathrm{VI})$ fluorides such as sulfonyl fluorides and fluorosulfates (Scheme 1b). However, the SuFEx reactivities of sulfonyl fluorides and fluorosulfates with $\mathrm{N}$-nucleophiles have not been fully unlocked. Viable $\mathrm{N}$-nucleophiles are limited to "deprotonated" amides and heterocycles such as imidazoles. ${ }^{[15]}$ Sulfonamidations with simple aliphatic and aromatic amines have met with limited success until recently. ${ }^{[16]}$ Most reactions with reasonable yields involved the use of activated substrates. Very recently, am Ende and Ball developed an elegant system for the activation of sulfur( $\mathrm{VI})$ fluorides. With 1.1 equiv of $\mathrm{Ca}\left(\mathrm{NTf}_{2}\right)_{2}$, a group of sulfonamides were prepared from sulfonyl fluorides in good to excellent yields (Scheme 1c). ${ }^{[17]}$ Strikingly, this protocol was also effective for the activation of less active fluorosulfates and sulfamoyl fluorides. However, the authors mentioned that a stoichiometric amount of calcium activator was required for reaction completion. It is highly desirable to develop a broad-spectrum, catalytic method for this synthetically useful transformation. In addition, sterically hindered substrates, which have been rarely investigated by existing methods, deserve special attention since bulky sulfonamides have shown promising properties in medicinal chemistry (e.g. Fedratinib and Penoxsulam). Herein, we present that a two-component catalytic system (cat. 1 hydroxybenzotriazole (HOBt) with a silicon additive) provides a 
general solution to the amidation of sulfonyl fluorides and fluorosulfates (Scheme 1d).

a) Conventional Sulfonyl Chloride Chemistry

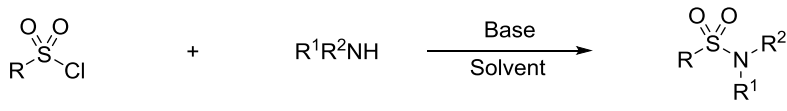

b) Catalytic Sulfonate and Sulfate Synthesis (Gembus and Sharpless)

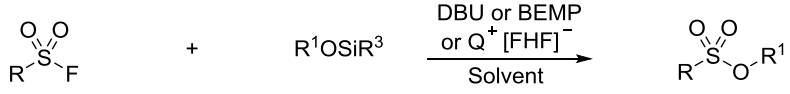

c) $\mathrm{Ca}\left(\mathrm{NTf}_{2}\right)_{2}$ Activated Sulfonamidation (am Ende and Ball)

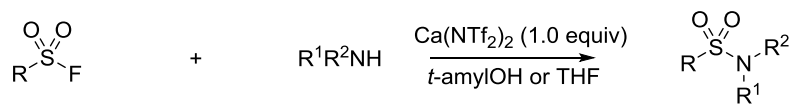

d) This work

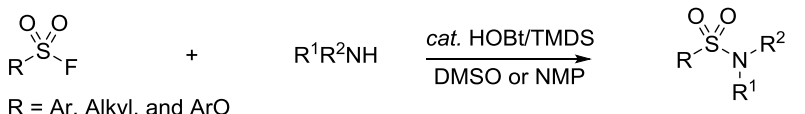

Scheme 1. Common amidation methods of sulfur(VI) halides.

\section{Results and Discussion}

This study started with our original efforts towards building a ligand library of ortho-phosphinoarenesulfonamides. ${ }^{[18]}$ Attempts on the preparation of ortho-phosphinoarenesulfonyl chlorides failed since the sulfonyl chloride group was incompatible with phosphines. Then, we turned our attention to the more stable ortho-phosphinoarenesulfonyl fluorides as precursors to sulfonamides. To ensure that the amidation protocol would be applicable for a broad range of substrates, we chose the reaction of 2-(diphenylphosphanyl)-5methylbenzenesulfonyl fluoride (1a) with bulky tert-butylamine (2a) as a model reaction. Unfortunately, only a small amount of the desired product 3a (up to $2 \%$ ) was obtained with literature methods (Table S1). We then decided to develop a more effective catalytic system to solve this challenge.

We focused on the development of new nucleophilic catalysts since fluoride ions were able to deactivate most Lewis acid catalysts. Mechanistically, an $\mathrm{S}_{\mathrm{N}} 2$ or addition-elimination pathway will be more favorable than $S_{N} 1$ pathway due to strong electric static interactions ${ }^{[19]}$ between $\mathrm{S}(\mathrm{VI})$ and $\mathrm{F}$. We speculated that the diminished reactivity for $\mathbf{1 a}$ with 1,8diazabicyclo[5.4.0]undec-7-ene (DBU) or 4-dimethylaminopyridine (DMAP) was attributed to the bulkiness of both substrates and intermediates. A highly congested transition state inhibited the reaction for sterically encumbered substrates. We proposed that a less sterically hindered catalyst may catalyze the targeted transformation.

O- and S-based nucleophiles have been widely used as stoichiometric activators in peptide chemistry ${ }^{[20]}$ but have been less recognized as catalysts. We first investigated a series of $\mathrm{O}-$ and $\mathrm{S}-$ nucleophiles with a broad $\mathrm{p} K_{\mathrm{a}}$ range in a stoichiometric amount. Gratifyingly, the reactions promoted by $\mathrm{HOBt}^{[21]}$ and its analogues gave the superior performance (Table 1, entries 7-9). The product 3a was obtained in $87 \%$ yield when the condition was set by utilizing HOBt (1.0 equiv) as an activator and anhydrous dimethyl sulfoxide (DMSO) as solvent (Table 1, entry 9). Only a trace amount of product was observed when the reactions were run with other activating reagents such as electron-deficient phenols, thiophenols, and hydroxy imides (Table 1, entries 1-6). Interestingly, Oxyma, ${ }^{[22]}$ an alternative of $\mathrm{HOBt}$ in peptide coupling, failed to promote the amidation (Table 1, entry 10).

Table 1. Optimization of the reaction conditions. ${ }^{[\mathrm{a}]}$

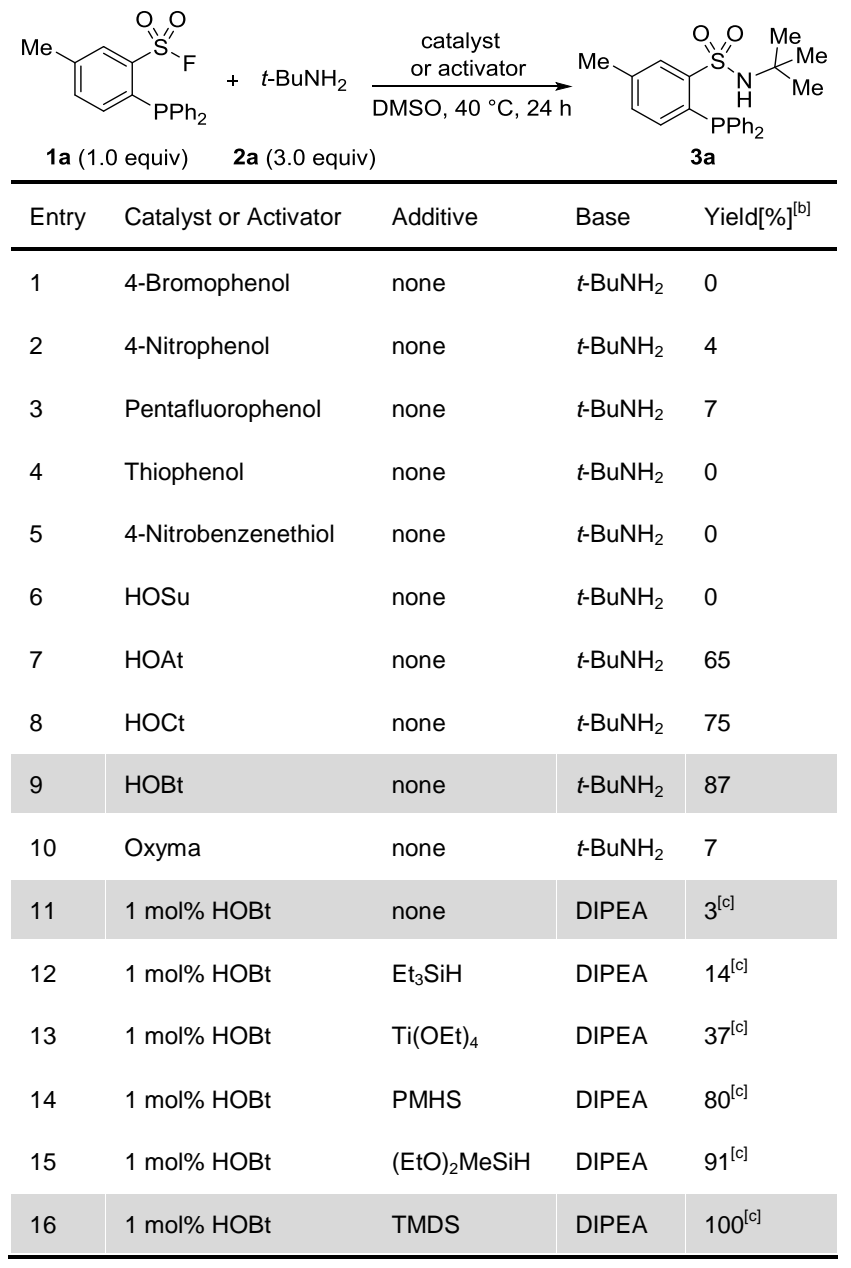

[a] Reactions were run with sulfonyl fluoride 1a $(0.20 \mathrm{mmol}), t-\mathrm{BuNH}_{2} 2 \mathrm{a}$ $(0.60 \mathrm{mmol})$, and activator $(0.20 \mathrm{mmol})$ in anhydrous DMSO $(0.25 \mathrm{~mL})$ at $40{ }^{\circ} \mathrm{C}$ for $24 \mathrm{~h}$. The full names of all abbreviations can be found in the supporting information. [b] The yield of $3 a$ was determined by ${ }^{31} \mathrm{P}$ NMR. [c] Reactions were run with sulfonyl fluoride 1a $(0.24 \mathrm{mmol}), t-\mathrm{BuNH}_{2} 2 \mathrm{2a}(0.20$ $\mathrm{mmol})$, HOBt $(1 \mathrm{~mol} \%)$, DIPEA $(0.40 \mathrm{mmol})$, and TMDS $(0.40 \mathrm{mmol})$ in anhydrous DMSO $(0.25 \mathrm{~mL})$ at $25^{\circ} \mathrm{C}$ for $24 \mathrm{~h}$.

Initial efforts with a catalytic amount of $\mathrm{HOBt}$ were unsuccessful (Table 1, entry 11). However, the addition of external fluoride scavengers ${ }^{[23]}$ enabled the catalyst turnover and significantly accelerated the reaction. Among the additives we tested, 1,1,3,3-tetramethyldisiloxane (TMDS) gave the optimal results (Table 1, entry 16 ). With only $1 \mathrm{~mol} \%$ catalyst loading, 3a was obtained in $100 \%$ yield at $25{ }^{\circ} \mathrm{C}$. Noticeably, more electrophilic chlorine-containing silicon reagents (Table S3, entries $2,5-6,8,15,19)$ yielded no expected products.

With the optimal conditions in hand, the substrate scope was explored with sulfonyl fluorides and amines (Table 2). We intentionally selected either bulky or less nucleophilic amines as substrates since the background reactions of these less active substrates were neglectable (no more than 5\%). Sulfonamides with diverse structures were obtained in excellent yields under our catalytic conditions. Strikingly, even in the cases that both reaction partners are sterically hindered and/or 
Table 2. Scope of amidation reactions of sulfonyl fluorides. ${ }^{[a]}$

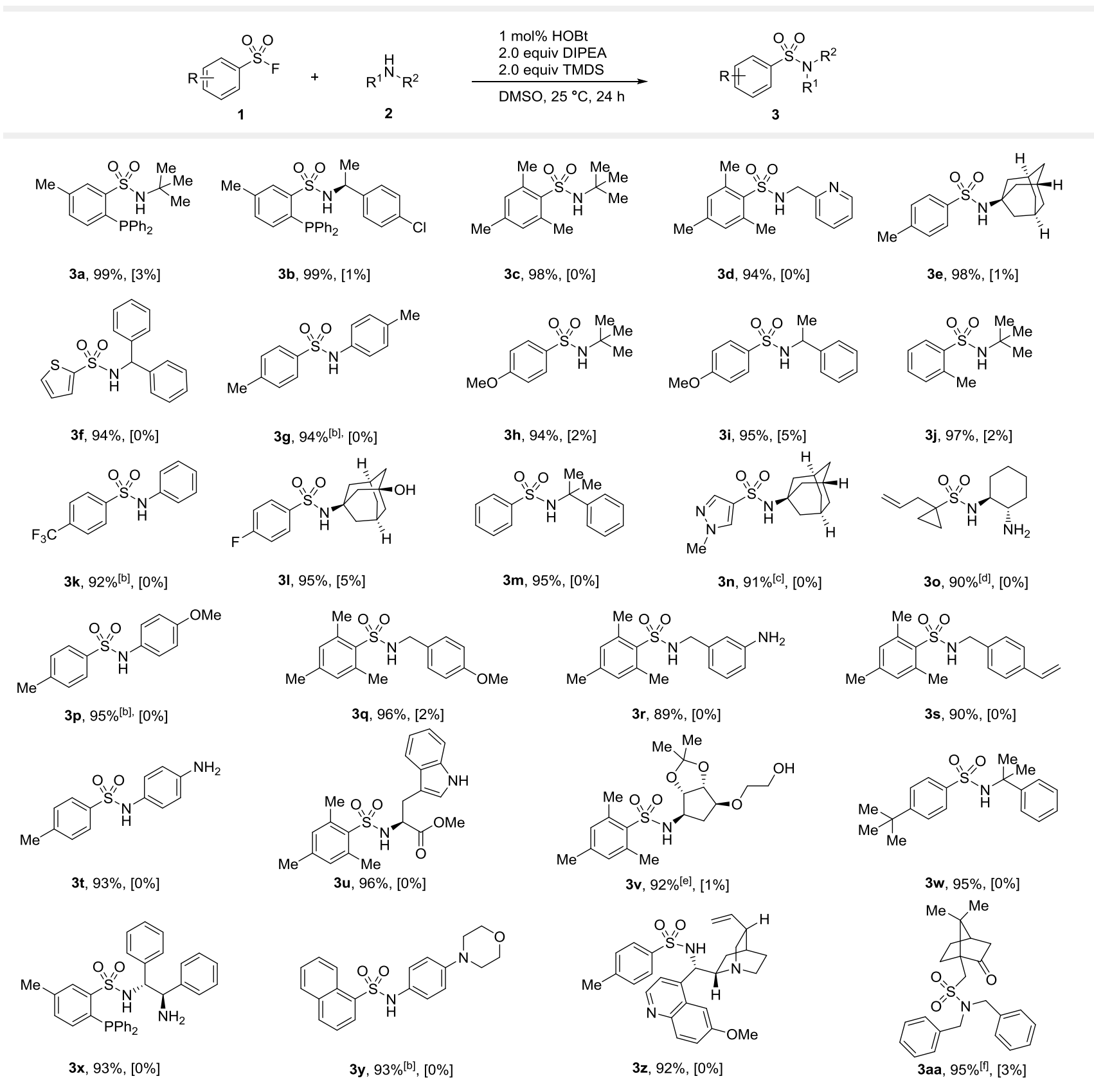

[a] Reactions were run with sulfonyl fluoride $1(1.20 \mathrm{mmol})$, amine $2(1.00 \mathrm{mmol}), \mathrm{HOBt}(1 \mathrm{~mol} \%)$, DIPEA (2.00 mmol), and TMDS (2.00 mmol) in anhydrous DMSO $(1.25 \mathrm{~mL})$ at $25^{\circ} \mathrm{C}$ for $24 \mathrm{~h}$. All yields were isolated yields. Yields in parentheses were for the control experiments in the absence of $\mathrm{HOBt}$ and TMDS and determined by $1 \mathrm{H}$ NMR using 1,3,5-trimethoxybenzene as an internal standard. [b] Reactions were run with sulfonyl fluoride 1 (1.0 equiv) and amine 2 (2.0 equiv). [c] Reaction was run at $60^{\circ} \mathrm{C}$. [d] Reaction was run with sulfonyl fluoride 1 (2.0 equiv) and $\mathrm{HOBt}(5 \mathrm{~mol} \%)$ at $60{ }^{\circ} \mathrm{C}$. [e] Reaction was run with sulfonyl fluoride 1 (1.5 equiv). [f] Reaction was run for $48 \mathrm{~h}$.

oxidation-sensitive, the desired products $\mathbf{3} \mathbf{a}-\mathbf{3} \mathbf{b}, \mathbf{3 x}$ were obtained in nearly quantitative yields. In addition, the current method well discriminated amino groups with different reactivity and hence retained the second amino group for later functionalization (Table 2, 30, 3r, 3t, 3x). Substrates with a hydroxyl group were also well tolerated (Table 2, 3l, 3v), which were somewhat problematic in sulfonyl chloride chemistry. Furthermore, the scope of amines was not restricted to alkyl amines. Less nucleophilic aromatic amines were also exemplified as viable substrates (Table $2, \mathbf{3 g}, \mathbf{3 k}$, 3t, 3p, 3y).
Next, we extended our methodology to more challenging fluorosulfates. Fluorosulfate is one of the essential building blocks in SuFEx chemistry. Although fluorosulfates react efficiently with phenols and their corresponding silyl ether, their reactions with amines are quite slow and complicated by multiple side reactions. Sulfamates are susceptible to a nucleophilic attack by water or amines. Side products such as phenolates, sulfamic acids, and sulfamides form under weakly basic and even neutral conditions. With a couple of modifications of our standard conditions, a broad range of structurally diverse fluorosulfates and amines were 


$$
\underbrace{}_{4} \begin{aligned}
& 5 \text { mol\% HOBt } \\
& 1.0 \text { equiv DIPEA } \\
& 2.0 \text { equiv TMDS } \\
& \text { DMSO, } 25^{\circ} \mathrm{C}, 24 \mathrm{~h}
\end{aligned}
$$<smiles>CCNc1cccc(OS(=O)(=O)N[C@H](C)C2CCCCC2)c1</smiles>

5a, $91 \%,[0 \%]$

5b, $88 \%,[0 \%]$

5c, $93 \%,[0 \%]$

5d, $91 \%,[0 \%]$

5e, $90 \%,[0 \%]$<smiles>COc1ccc(OS(=O)(=O)N[C@H](C)c2ccccc2)cc1</smiles>

5f, $92 \%$, [2\%]<smiles>CCCN(CCC)S(=O)(=O)Oc1ccc(OC)cc1</smiles>

$\mathbf{5 g}, 93 \%,[0 \%]$<smiles>CC(C)c1ccc(OS(=O)(=O)NC(C)(C)C)cc1</smiles>

5h, $92 \%,[0 \%]$<smiles>CC(C)c1ccc(OS(=O)(=O)NC(C)c2ccccc2)cc1</smiles>

5i, $94 \%,[0 \%]$<smiles>C=CCN(CC=C)S(=O)(=O)Oc1ccc(I)cc1</smiles>

5j, $93 \%$, [0\%]<smiles>Cc1cc(C)cc(OS(=O)(=O)N[C@]23CC[C@H](C[C@H](O)C2)C3)c1</smiles>

5k, $87 \%,[0 \%]$<smiles>O=S(=O)(N[C@H]1CCCc2ccccc21)Oc1ccc2c(c1)OCO2</smiles><smiles>C[C@@H](NS(=O)(=O)Oc1ccccc1)c1ccccc1</smiles>

5m, $90 \%{ }^{[\mathrm{b}]},[0 \%]$

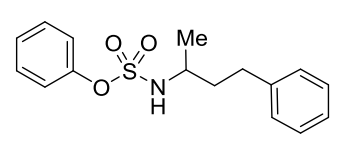

5n, $91 \%{ }^{[\mathrm{b}]},[2 \%]$
$\overbrace{0}^{B r}$

5o, $94 \%{ }^{[c]},[1 \%]$<smiles>COc1ccc(OS(=O)(=O)N[C@@H]2C[C@@H]3C[C@H](O)[C@H](C3)C2)cc1</smiles>

5p, $90 \%$, [0\%]

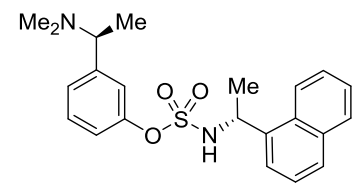

5t, $96 \%,[0 \%]$<smiles>CC(CCc1ccccc1)NS(=O)(=O)Oc1ccc(C(C)C)cc1</smiles>

5q, $95 \%{ }^{[b]},[2 \%]$<smiles>CC(C)(C)c1cc(OS(=O)(=O)N2CCC3(CC2)OCCO3)cc(C(C)(C)C)c1</smiles>

$5 u, 93 \%[d],[4 \%]$

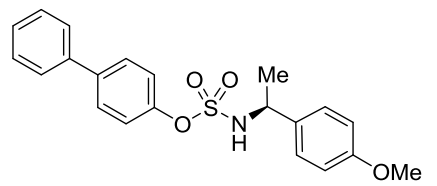

5r, $90 \%$, [5\%]<smiles>CC[C@H]1CC[C@H](c2ccc(OS(=O)(=O)N[C@@H](C)c3cccc4ccccc34)cc2)CC1</smiles>

5s, $93 \%$, [0\%]

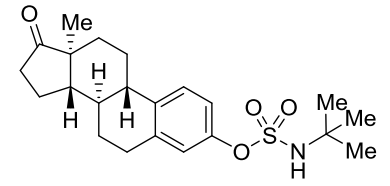

5v, $91 \%,[0 \%]$<smiles>[CH][C@@]12CC[C@@H]3c4ccc(OS(=O)(=O)N[C@H](CC)c5ccccc5)cc4CC[C@H]3[C@@H]1CC[C@@]2(O)C#C</smiles>

5w, $90 \%,[0 \%]$

[a] Reactions were run with fluorosulfates 4 (2.00 mmol), amine $2(1.00 \mathrm{mmol}), \mathrm{HOBt}(5 \mathrm{~mol} \%)$, DIPEA (1.00 mmol), and TMDS (2.00 mmol) in anhydrous DMSO $(1.25 \mathrm{~mL})$ at $25^{\circ} \mathrm{C}$ for $24 \mathrm{~h}$. All yields were isolated yields. Yields in parentheses were for the control experiments in the absence of $\mathrm{HOBt}$ and TMDS and determined by $1 \mathrm{H}$ NMR using 1,3,5-trimethoxybenzene as an internal standard. [b] Reactions were run in NMP. [c] Reaction was run with fluorosulfates 4 ( 1.0 equiv) and amine 2 (2.0 equiv) for 48 h. [d] Reaction was run with (TMS) 20 in NMP at $50^{\circ} \mathrm{C}$.

transformed into the desired sulfamate products smoothly (Table 3). Most of amine substrates were branched and even sterically hindered, and all of sulfamate products were generally obtained in excellent yields. Strikingly, even the reactions with tert-butyl amine and amantadine furnished the corresponding sulfamates $5 a-5 d, 5 h, 5 k, 5 p$, and $5 v$ in satisfactory yields.

Furthermore, we applied our methodology to synthesize the orphan drug of myelofibrosis, Fedratinib, ${ }^{[24]}$ which was approved by US-FDA very recently. The original route for Fedratinib went through an early-stage amidation of sulfonyl chloride with $\mathbf{2 a}$, followed by two nucleophilic aromatic substitutions. Instead of a sulfonyl chloride, our new route started with readily available 3-nitrobenzenesulfonyl fluoride $\mathbf{8}$, followed by reduction and sequential nucleophilic aromatic substitutions to generate the key intermediate 13 . To complete the synthesis of Fedratinib 14, a late-stage amidation of bench-stable sulfonyl fluoride 13 was conducted and the desired product 14 (1.22 g, 93\% yield) was obtained under our protocols. The route via sulfonyl fluoride enables the late-stage functionalization and diversification of Fedratinib at the sulfonamide terminal and hence provides a facile entry to access Fedratinib analogues for further biological screening.

To demonstrate the potential of our catalytic system in process chemistry, a multidecagram-scale reaction was conducted with $\mathbf{1 i}$ and $\mathbf{2 d}$ with a $0.02 \mathrm{~mol} \%$ catalyst loading (Scheme 3). $32.8 \mathrm{~g}$ of sulfonamide 15 was isolated in $90 \%$ yield with the use of only $3.4 \mathrm{mg}$ of $\mathrm{HOBt}$ catalyst, and no chromatography was needed for purification. In contrast, $\mathbf{1 i}$ significantly decomposed under the condition without $\mathrm{HOBt}$ and TMDS.

To understand the roles of $\mathrm{HOBt}$ and TMDS, we performed a series of experiments for the discovered catalytic system (Scheme 4). We prepared the proposed key intermediate $N$-hydroxybenzotriazole sulfonate $^{[25]} \mathbf{1 6}$. 


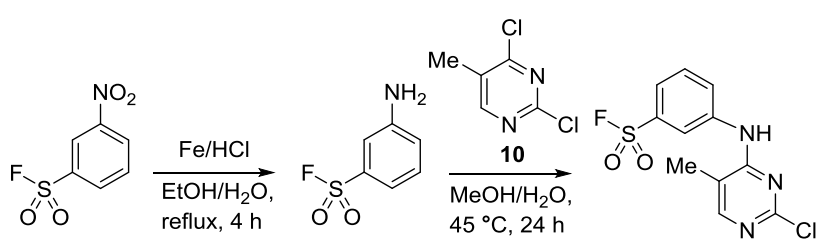

8<smiles>Nc1ccc(OCCN2CCCC2)cc1</smiles>

$9,81 \%$ yield

$11,88 \%$ yield

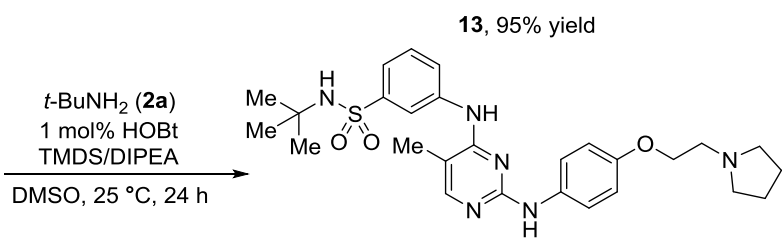

14, Fedratinib, $1.22 \mathrm{~g}, 93 \%$ yield

Scheme 2. Synthesis of Fedratinib via a sulfonyl fluoride intermediate.

Although 16 was unstable in DMSO, we were able to carry out the mechanistic experiments in $N$-methyl-2-pyrrolidinone (NMP) instead. Experiments (Scheme 4, eq a) indicated that TMDS promoted the formation of $\mathbf{1 6}$. Without a silicon additive, only a trace amount of $\mathbf{1 6}$ formed at elevated temperature. On the other hand, the consumption of $\mathbf{1 6}$ with amines (Scheme 4 , eq b)

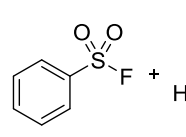

$1 \mathrm{i}, 20.0 \mathrm{~g}$ $125.0 \mathrm{mmol}$

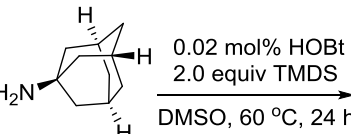

光

2d, 2.0 equiv

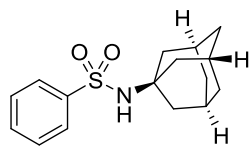

$15,32.8 \mathrm{~g}, 90 \%$ yield
Scheme 3. Multidecagram-scale derivatization of antiviral drug amantadine.

was faster than its formation. It suggested that the step of the activation of $\mathrm{S}(\mathrm{VI})-\mathrm{F}$ bond to form $\mathbf{1 6}$ was the rate-determining

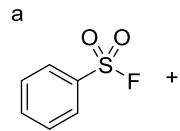

$1 \mathrm{i}$

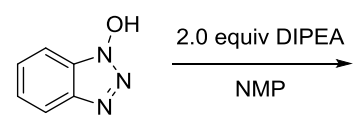

1.0 equiv

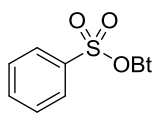

16 with TMDS, $25^{\circ} \mathrm{C}, 30 \mathrm{~min}, 39 \%$ yield; $120 \mathrm{~min}, 61 \%$ yield. (in ${ }^{1} \mathrm{H} \mathrm{NMR}$ ) w/o TMDS, $25 / 60^{\circ} \mathrm{C}, 120 \mathrm{~min}$, trace products<smiles>CCOS(=O)(=O)c1ccccc1</smiles>

16

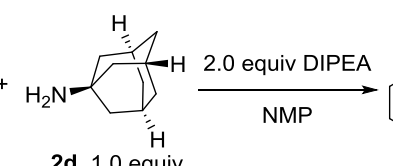

2 d, 1.0 equiv

with TMDS, $120 \mathrm{~min}, 82 \%$ yield.

w/o TMDS, $30 \mathrm{~min}, 86 \%$ yield; $120 \mathrm{~min}, 84 \%$ yield.

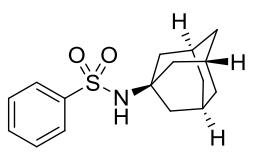

15 (in ${ }^{1} \mathrm{H}$ NMR) step for the overall process. Another finding was that TMDS did not promote the formation of sulfonamide 15 .

The proposed reaction pathway was also verified with our preliminary computational studies (Scheme 5). It starts with a nucleophilic attack of ${ }^{-} \mathrm{OBt}$ anion to the electrophilic S(VI) center. The subsequent fluoride departure drives the formation of INT-2, which is $3.3 \mathrm{kcal} / \mathrm{mol}$ higher than the starting complex INT-1. This is consistent with the experimental results (Scheme 4, eq a) that $N$-hydroxybenzotriazole sulfonate 16 was not detected without the addition of TMDS. Although the exact roles of silicon additives are not completely clear, our experimental results indicate that it can abstract the generated fluoride ions and promote the formation of key intermediate 16. Compared to the first step of activation (INT-1 to TS-1: $20.6 \mathrm{kcal} / \mathrm{mol}$ ), the second step of amidation went through a slightly lower transition state (INT-2 to TS-2: $20.1 \mathrm{kcal} / \mathrm{mol}$ ). This result also supported our mechanistic experiments that the generation of intermediate 16 is slower than the amidation (Scheme 4).

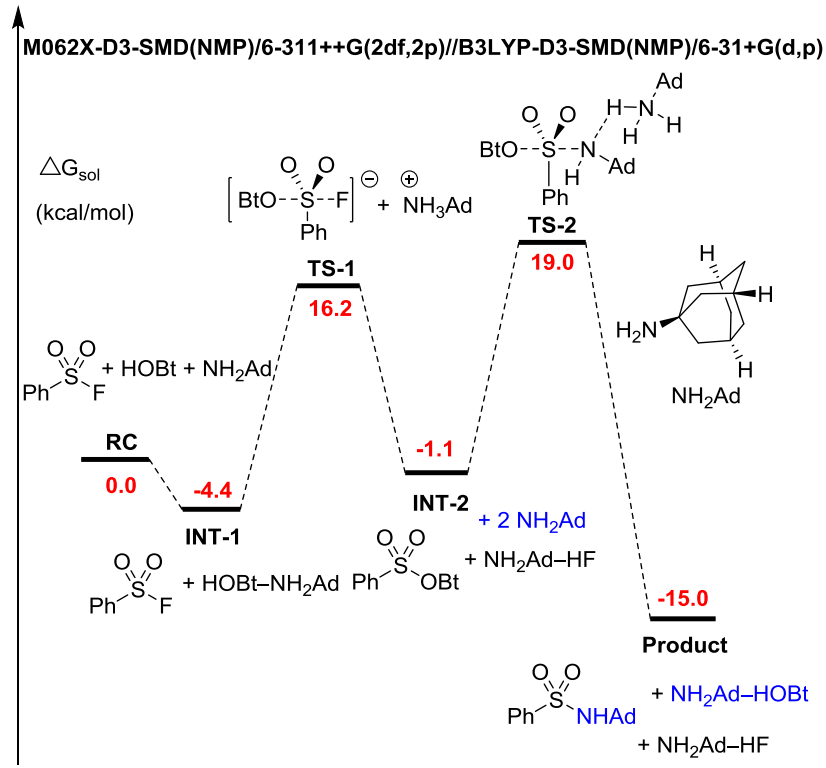

Scheme 5. Calculated reaction pathways

\section{Conclusion}

In summary, we have developed a broad-spectrum, catalytic method for the synthesis of sulfonamides and sulfamates from sulfonyl fluorides and fluorosulfates. With this methodology, we are able to access a set of sterically hindered sulfonamides and sulfamates with excellent yields including the marketed drug Fedratinib. The experimental and mechanistic results have revealed that $\mathrm{HOBt}$ is an outstanding nucleophilic catalyst to activate $\mathrm{S}(\mathrm{VI})-\mathrm{F}$ bond. Further elucidation of detailed mechanisms and applications of this catalytic system to other transformations are currently under our investigation.

\section{Acknowledgements}

Financial support from the National Natural Science Foundation of China (No. 21502241) and the Natural Science Foundation of Guangdong Province (No. 2016A030313290) is gratefully acknowledged. The authors also thank Supercomputing Center 
in Shenzhen (Shenzhen Cloud Computer Center) and Sun Yatsen University for providing computing resources. L.L. thanks Prof. Suhua Li (Sun Yat-sen University), Prof. Daniel Seidel (University of Florida), Prof. Seth B. Herzon (Yale University), Prof. Yiyun Chen (SIOC), and Pyh Li for helpful discussions and support.

\section{Conflict of interest}

Sun Yat-sen University has filed two patent applications.

Keywords: SuFEx reaction • sterically hindered $•$ sulfonamides • sulfamates $\cdot$ nucleophilic catalyst $\bullet$ organocatalysis

[1] a) S. Apaydin, M. Török. Bioorg. Med. Chem. Lett. 2019, 29, 2042 2050; b) K. A. Scott, J. T. Njardarson, Top. Curr. Chem. 2018, 376, 5; (c) F. A. Khan, S. Mushtaq, S. Naz, U. Farooq, A. Zaidi, S. M. Bukhari, A. Rauf, M. S. Mubarak, Curr. Org. Chem. 2018, 22, 818-830; (d) C. T. Supuran, Molecules 2017, 22, 1642; e) P. Devendar; G-F. Yang, Top. Curr. Chem. 2017, 375, 82; f) M. Feng, B. Tang, S. H. Liang, X. Jiang Curr. Top. Med. Chem. 2016, 16, 1200-1216; g) N. A. McGrath, M. Brichacek, J. T. Njardarson, J. Chem. Educ. 2010, 87, 1348-1349; h) J. D. Wilden, J. Chem. Res. 2010, 541-548; i) A. Scozzafava, T. Owa, A Mastrolorenzo, C. T. Supuran, Curr. Med. Chem. 2003, 10, 925-953.

[2] Selected examples in recent literature: a) X. Wang, M. Yang, Y. Kuang, J.-B. Liu, X. Fan, J. Wu. Chem. Commun. 2020, 56, 3437-3440; b) K Chen, W. Chen, B. Han, W. Chen, M. Liu, H. Wu, Org. Lett. 2020, 22 1841-1845; c)G. Laudadio, E. Barmpoutsis, C. Schotten, L. Struik, S. Govaerts, D. L. Browne, T. Noël, J. Am. Chem. Soc. 2019, 141, 56645668; d) N. Eid, I. Karamé, B. Andrioletti, Eur. J. Org. Chem. 2018, 5016-5022; e) O. M. Mulina, A. I. llovaisky, A. O. Terent'ev, Eur. J. Org Chem. 2018, 4648-4672; f) P. K. Shyam, H.-Y. Jang, J. Org. Chem. 2017, 82, 1761-1767; g) A. S. Deeming, C. J. Russell, M. C. Willis, Angew. Chem. Int. Ed. 2015, 54, 1168-1171; 9182; Angew. Chem. 2015, 127, 1184-1187; h) K. Yang, M. Ke, Y. Lin, Q. Song, Green Chem. 2015, 17, 1395-1399; i) W. Zhang, J. Xie, B. Rao, M. Luo, J. Org. Chem. 2015, 80, 3504-3511; j) W. Wei, C. Liu, D. Yang, J. Wen, J. You, H. Wang, Adv. Synth. Catal. 2015, 357, 987-992; k) X. Tang, L. Huang, C. Qi, X. Wu, W. Wu, H. Jiang, Chem. Commun. 2013, 49, 6102-6104;

[3] Selected examples in recent literature: a) R. T. McGuire, C. M. Simon, A. A. Yadav, M. J. Ferguson, M. Stradiotto, Angew. Chem. Int. Ed. 2020, 59, 8952-8956; Angew. Chem. 2020, 132, 9037-9041; b) S. D. Laffoon, V. S. Chan, M. G. Fickes, B. Kotecki, A. R. Ickes, J. Henle, J. G. Napolitano, T. S. Franczyk, T. B. Dunn, D. M. Barnes, A. R. Haight, R. F. Henry, S. Shekhar, ACS Catal. 2019, 9, 11691-11708; c) J. Becica, D. P. Hruszkewycz, J. E. Steves, J. M. Elward, D. C. Leitch, G. E. Dobereiner, Org. Lett. 2019, 21, 8981-8986; d) T. Kim, S. J. McCarver, C. Lee, D. W. C. MacMillan, Angew. Chem. Int. Ed. 2018, 57, 3488-3492; Angew. Chem. 2018, 130, 3546-3550; e) Y. Chen, P. R. D. Murray, A. T. Davies, M C. Willis J. Am. Chem. Soc. 2018, 140, 87818787; f) S.-Y. Moon, J. Nam, K. Rathwell, W.-S. Kim, Org. Lett. 2014, 16, 338-341; g) S. Shekhar, T. B. Dunn, B. J. Kotecki, D. K. Montavon, S. C. Cullen, J. Org. Chem. 2011, 76, 4552-4563; h) B. B. Rosen, J. C. Ruble, T. J. Beauchamp, A. Navarro, Org. Lett. 2011, 13, 2564-2567; i) J. B. Grimm, M. H. Katcher, D. J. Witter, A. B. Northrup, J. Org. Chem. 2007, 72, 8135-8138; j) W. Deng, L. Liu, C. Zhang, M. Liu, Q.-X. Guo, Tetrahedron Lett. 2005, 46, 7295-7298.

[4] Selected examples in recent literature: a) P. T. Marcyk, L. R. Jefferies, D. I. AbuSalim, M. Pink, M.-H. Baik, S. P. Cook, Angew. Chem. Int. Ed. 2019, 58, 1727-1731; Angew. Chem. 2019, 131, 1741-1745; b) B. G. Reed-Berendt, L. C. Morrill, J. Org. Chem. 2019, 84, 3715-3724; c) T. Verdelet, R. M. Ward, D. G. Hall, Eur. J. Org. Chem. 2017, 5729-5738 d) Y. Chen, Synthesis 2016, 48, 2483-2522; e) T. Nishikata, H. Nagashima, Angew. Chem. Int. Ed. 2012, 51, 5363-5366; Angew. Chem. 2012, 124, 5459-5462; f) F. Shi, M. K. Tse, X. Cui, D. Gördes, D. Michalik, K. Thurow, Y. Deng, M. Beller, Angew. Chem. Int. Ed. 2009 ,
48, 5912-5915; Angew. Chem. 2009, 121, 6026-6029; g) M. H. S. A Hamid, C. L. Allen, G. W. Lamb, A. C. Maxwell, H. C. Maytum, A. J. A. Watson, J. M. J. Williams, J. Am. Chem. Soc. 2009, 131,1766-1774; h) F. Shi, M. K. Tse, Sh. Zhou, M.-M. Pohl, J. Radnik, S. Hübner, K. Jähnisch, A. Brückner, M. Beller, J. Am. Chem. Soc. 2009, 131, 17751779.

[5] Selected examples in recent literature: a) H. Hayashi, T. Uchida, Eur. J. Org. Chem. 2020, 909-916; b) F. Wu, J. P. Ariyarathna, N. Kaur, N.-E. Alom, M. L. Kennell, O. H. Bassiouni, W. Li, Org. Lett. 2020, 22, 2135 2140; c) A. E. Bosnidou, K. Muñiz, Angew. Chem. Int. Ed. 2019, 58 7485-7489; Angew. Chem. 2019, 131, 7564-7568; d) Y. Park, Y. Kim, S. Chang, Chem. Rev. 2017, 117, 9247-9301; e) V. Bagchi, P. Paraskevopoulou, P. Das, L. Chi, Q. Wang, A. Choudhury, J. S. Mathieson, L. Cronin, D. B. Pardue, T. R. Cundari, G. Mitrikas, Y Sanaki, P. Stavropoulos, J. Am. Chem. Soc. 2014, 136,11362-11381; f) G. Dequirez, V. Pons, P. Dauban, Angew. Chem. Int. Ed. 2012, 51, 7384-7395; Angew. Chem. 2012, 124, 7498-7510.

[6] Selected reviews in recent literature: a) T. C. Das, S. A. Quadri, M. Farooqui, Chem. Biol. Interface 2018, 8, 194-204; b) M. Ashfaq, S. S. A. Shah, T. Najjam, S. Shaheen, G. Rivera, Mini-Rev. Org. Chem. 2013, 10, 160-170.

[7] (a) F. W. Goldberg, J. G. Kettle, T. Kogej, M. W.D. Perry, N. P Tomkinson, Drug Discovery Today 2015, 20, 11-17; (b) A. V. Bogolubsky, Y. S. Moroz, P. K. Mykhailiuk, S. E. Pipko, A. I. Konovets, I. V. Sadkova, A. Tolmachev, ACS Comb. Sci. 2014, 16, 192-197; (c) K. Bahrami, M. M. Khodaei, J. Abbasi, Tetrahedron 2012, 68, 5095-5101; (d) S. W. Wright, K. N Hallstrom, J. Org. Chem. 2006, 71,1080-1084.

[8] Selected reviews in recent literature: a) N. D. Ball, "Properties and Applications of Sulfur(VI) Fluorides" in Emerging Fluorinated Motifs. Properties, Synthesis and Applications, (Eds.: J.-A. Ma, D. Cahard) Wiley-VCH, Weinheim, 2020, pp. 621-674; b) Y.-P. Meng, S.-M. Wang, W.-Y. Fang, Z.-Z. Xie, J. Leng, H. Alsulami, H.-L. Qin, Synthesis 2020, 52, 673-687; c) R. Lekkala, R. Lekkala, B. Moku, K. P. Rakesh H.-L. Qin, Org. Chem. Front. 2019, 6, 3490-3516; d) P. K. Chinthakindi, P. I. Arvidsson, Eur. J. Org. Chem. 2018, 3648-3666.

[9] a) A. S. Barrow, C. J. Smedley, Q. Zheng, S. Li, J. Dong, J. E. Moses, Chem. Soc. Rev. 2019, 48, 4731-4758; b) T. A. Fattah, A. Saeed, F. Albericio, J. Fluorine Chem. 2018, 213, 87-112; c) L. Revathi, L. Ravindar, J. Leng, K. P. Rakesh, H.-L. Qin, Asian J. Org. Chem. 2018 7, 662-682. d) A. Dondoni, A. Marra, Org. Biomol. Chem. 2017, 15, 1549-1553; e) B. Gao, L. Zhang, Q. Zheng, F. Zhou, L. M. Klivansky, J Lu, Y. Liu, J. Dong, P. Wu, K. B. Sharpless, Nat. Chem. 2017, 9, 10831088; f) J. Dong, L. Krasnova, M. G. Finn, K. B. Sharpless, Angew. Chem. Int. Ed. 2014, 53, 9430-9448; Angew. Chem. 2014, 126, 9584 9603

[10] a) G. Meng, T. Guo, T. Ma, J. Zhang, Y. Shen, K. B. Sharpless, J. Dong, Nature 2019, 574, 86-89; b) T. Guo, G. Meng, X. Zhan, Q. Yang, T. Ma, L. Xu, K. B. Sharpless, J. Dong, Angew. Chem. Int. Ed. 2018, 57, 2605-2610; Angew. Chem. 2018, 130, 2635-2640; c) H. Zhou, P. Mukherjee, R. Liu, E. Evrard, D. Wang, J. M. Humphrey, T. W. Butler, L. R. Hoth, J. B. Sperry, S. K. Sakata, C. J. Helal, C. W. am Ende, Org. Lett. 2018, 20, 812-815; d) B. Gao, S. Li, P. Wu, J. E. Moses, K. B. Sharpless, Angew. Chem. Int. Ed. 2018, 57, 1939-1943; Angew. Chem. 2018, 130, 1957-1961; e) S. Li, P. Wu, J. E. Moses, K. B. Sharpless, Angew. Chem. Int. Ed. 2017, 56, 2903-2908; Angew. Chem. 2017, 129, 2949-2954.

[11] a) S. Kitamura, Q. Zheng, J. L. Woehl, A. Solania, E. Chen, N. Dillon, M. V. Hull, M. Kotaniguchi, J. R. Cappiello, S. Kitamura, V. Nizet, K. B. Sharpless, D. W. Wolan, J. Am. Chem. Soc. 2020, 142, 10899-10904; b) C. J. Smedley, G. Li, A. S. Barrow, T. L. Gialelis, M.-C. Giel, A Ottonello, Y. Cheng, S. Kitamura, D. W. Wolan, K. B. Sharpless, J. E. Moses, Angew. Chem. Int. Ed. 2020, 59, 12460-12469; Angew. Chem. 2020, 132, 12560-12569 c) P. Martín-Gago, C. A. Olsen, Angew. Chem. Int. Ed. 2019, 58, 957-966; Angew. Chem. 2019, 131, 969-978 d) H. Xu, F. Ma, N. Wang, W. Hou, H. Xiong, F. Lu, J. Li, S. Wang, P. Ma, G. Yang, R. A. Lerner, Adv. Sci. 2019, 6, 1901551; e) Q. Zheng, J. L. Woehl, S. Kitamura, D. Santos-Martins, C. J. Smedley, G. Li, S. Forli, J. E. Moses, D. W. Wolan, K. B. Sharpless, Proc. Natl. Acad. Sci. U. S A 2019, 116, 18808-18814; f) D. E. Mortenson, G. J. Brighty, L. Plate, G. Bare, W. Chen, S. Li, H. Wang, B. F. Cravatt, S. Forli, E. T. Powers, K. B. Sharpless, I. A. Wilson, J. W. Kelly, J. Am. Chem. Soc. 2018, 140, 
200-210; g) Z. Liu, J. Li, S. Li, G. Li, K. B. Sharpless, P. Wu, J. Am. Chem. Soc. 2018, 140, 2919-2925.

[12] a) F. Liu, H. Wang, S. Li, G. A. L. Bare, X. Chen, C. Wang, J. E. Moses, P. Wu, K. B. Sharpless, Angew. Chem. Int. Ed. 2019, 58, 8029-8033; Angew. Chem. 2019, 131, 8113-8117; b) N. Wang, B. Yang, C. Fu, H. Zhu, F. Zheng, T. Kobayashi, J. Liu, S. Li, C. Ma, P. G. Wang, Q. Wang, and L. Wang, J. Am. Chem. Soc. 2018, 140, 4995-4999; c) W. Chen, J. Dong, S. Li, Y. Liu, Y.Wang, L. Yoon, P.Wu, K. B. Sharpless, J.W. Kelly, Angew. Chem. Int. Ed. 2016, 55, 1835-1838; Angew. Chem. 2016, 128, 1867-1870; d) W. Chen, J. Dong, L. Plate, D. E. Mortenson, G. J. Brighty, S. Li, Y. Liu, A. Galmozzi, P. S. Lee, J. J. Hulce, B. F. Cravatt, E. Saez, E. T. Powers, I. A. Wilson, K. B. Sharpless, J. W. Kelly, J. Am Chem. Soc. 2016, 138, 7353-7364; e) A. Baranczak, Y. Liu, S. Connelly, W.-G. H. Du, E. R. Greiner, J. C. Genereux, R. L. Wiseman Y. S. Eisele, N. C. Bradbury, J. Dong, L. Noodleman, K. B. Sharpless, I. A. Wilson, S. E. Encalada, J. W. Kelly, J. Am. Chem. Soc. 2015, 137, 7404-7414; f) A. Narayanan, L. H. Jones, Chem. Sci. 2015, 6, 2650 2659.

[13] a) R. W. Kulow, J. W. Wu, C. Kim, Q. Michaudel, Chem. Sci. 2020, 11, 7807-7812; b) P. Demay-Drouhard, K. Du, K. Samanta, X. Wan, W Yang, R. Srinivasan, A. C. H. Sue, H. Zuilhof, Org. Lett. 2019, 21, 3976-3980; c)S. Park, H. Song, N. Ko, C. Kim, K. Kim, E. Lee, ACS Appl. Mater. Interfaces 2018, 10, 33785-33789; d) C. Yang, J. P. Flynn, J. Niu, Angew. Chem. Int. Ed. 2018, 57, 16194-16199; Angew. Chem. 2018, 130,16426-16431; e) D. Gahtory, R. Sen, S. Pujari, S. Li, Q. Zheng, J. E. Moses, K. B. Sharpless, H. Zuilhof, Chem. Eur. J. 2018, 24, 10550-10556; f) T. Hmissa, X. Zhang, N. R. Dhumal, G. J. McManus, X. Zhou, H. B. Nulwala, A. Mirjafari, Angew. Chem. Int. Ed. 2018, 57,16005-16009; Angew. Chem. 2018, 130, 16237-16241; g) H. Wang F. Zhou, G. Ren, Q. Zheng, H. Chen, B. Gao, L. Klivansky, Y. Liu, B. Wu, Q. Xu, J. Lu, K. B. Sharpless, P. Wu, Angew. Chem. Int. Ed. 2017, 56, 11203-11208; Angew. Chem. 2017, 129, 11355-11360; h) J. Yatvin, K. Brooks, J. Locklin, Angew. Chem. Int. Ed. 2015, 54, 13370 13373; Angew. Chem. 2015, 127, 13568-13571; i) J. Dong, K. B. Sharpless, L. Kwisnek, J. S. Oakdale, V.V. Fokin, Angew. Chem. Int. Ed. 2014, 53, 9466-9470; Angew. Chem. 2014, 126, 9620-9624.

[14] V. Gembus, F. Marsais, V. Levacher, Synlett 2008, 1463-1466.

[15] a) P. Gilles, C. Veryser, S. Vangrunderbeeck, S. Ceusters, L. V. Meervelt, W. M. De Borggraeve, J. Org. Chem. 2019, 84, 1070-1078; b) S. Zhang, H. Xiong, F. Lu, F. Ma, Y. Gu, P. Ma, H. Xu, G. Yang. J. Org. Chem. 2019, 84, 15380-15388

[16] a) R. Zelli, S. Tommasone, P. Dumy, A. Marra, A. Dondoni, Eur. J. Org. Chem. 2016, 5102-5116; (b) S. Berg, M. Bergh, S. Hellberg, K. Högdin, Y. Lo-Alfredsson, P. Söderman, S. von Berg, T. Weigelt, M. Ormö, Y Xue, J. Tucker, J. Neelissen, E. Jerning, Y. Nilsson, R. Bhat, J. Med. Chem. 2012, 55, 9107-9119; c) F. Toulgoat, B. R. Langlois, M Médebielle, J.-Y. Sanchez, J. Org. Chem. 2008, 73, 5613-5616; (d) P. A. Harris, M. Cheung, R. N. Hunter III, M. L. Brown, J. M. Veal, R. T. Nolte, L. Wang, W. Liu, R. M. Crosby, J. H. Johnson, A. H. Epperly, R. Kumar, D. K. Luttrell, J. A. Stafford, J. Med. Chem. 2005, 48, 1610 1619; e) G. R. Bebernitz, T. D. Aicher, J. L. Stanton, J. Gao, S. S. Shetty, D. C. Knorr, R. J. Strohschein, J. Tan, L. J. Brand, C. Liu, W. H. Wang, C. C. Vinluan, E. L. Kaplan, C. J. Dragland, D. DelGrande, A. Islam, R. J. Lozito, X. Liu, W. M. Maniara, W. R. Mann, J. Med. Chem. 2000, 43, 2248-2257. f) J. Lu, T. Zhou, E. Zhang, (Asymchem Life Science (Tianjin) Co., Ltd.), CN 107266392 A, 2017.

[17] a) S. Mahapatra, C. P. Woroch, T. W. Butler, S. N. Carneiro, S. C. Kwan, S. R. Khasnavis, J. Gu, J. K. Dutra, B. C. Vetelino, J. Bellenger, C. W. am Ende, N. D. Ball, Org. Lett. 2020, 22, 4389-4394; b) P. Mukherjee, C. P. Woroch, L. Cleary, M. Rusznak, R. W. Franzese, M. R Reese, J. W. Tucker, J. M. Humphrey, S. M. Etuk, S. C. Kwan, C. W. am Ende, N. D. Ball, Org. Lett. 2018, 20, 3943-3947.

[18] a) W. Luo, Z. Wang, X. Cao, D. Liang, M. Wei, K. Yin, L. Li, J. Org. Chem. 2020, doi: 10.1021/acs.Joc.0c01309; b) L. Li, D. Liang, X. Cao, Z. Wang, (Sun Yat-sen University), WO 2019206166 A1, 2019. c) L. Li, D. Liang, X. Cao, (Sun Yat-sen University), CN 108484668 A, 2018. d) L. Li, D. Liang, Z. Wang, (Sun Yat-sen University), CN 108467409 A, 2018.

[19] a) T. A. Hamlin, M. Swart, F. M. Bickelhaupt, ChemPhysChem 2018, 19, 1315-1330; b) D. D. Sung, T. J. Kim, I. Lee, J. Phys. Chem. A 2009, 113, 7073-7079; c) I. Lee, C. K. Kim, H. G. Li, C. K. Sohn, C. K. Kim, H
W. Lee, B.-S. Lee, J. Am. Chem. Soc. 2000, 122, 11162-11172; d) I. Lee, H. K. Kang, H. W. Lee, J. Am. Chem. Soc. 1987, 109, 7472-7477.

[20] Selected reviews in recent literature: a) T. I. Al-Warhi, H. M. A. AlHazimi, A. El-Faham, J. Saudi Chem. Soc. 2012, 16, 97-116; b) A. ElFaham, F. Albericio, Chem. Rev. 2011, 111, 6557-6602; c) E. Valeur, M. Bradley, Chem. Soc. Rev. 2009, 38, 606-631.

[21] a) W. König, R. Geiger, Chem. Ber. 1970, 103, 788-798; b) W. König, R. Geiger, Chem. Ber. 1970, 103, 2034-2040.

[22] R. Subirs-Funosas, R. Prohens, R. Barbas, A. El-Faham, F. Albericio, Chem. Eur. J. 2009, 15, 9394-9403.

[23] J. W. Gillard, R. Fortin, H. E. Morton, C. Yoakim, C. A. Quesnell, S Daignault, Y. Guindon, J. Org. Chem. 1988, 53, 2602-2608.

[24] a) M. Ragheb, C. N. Harrison, D. P. McLornan, Future Oncol. 2020, 16, 175-186; b) J. Arvind, C. Janice, T. Ayalew, (TargeGen, Inc.), WO 2012061833 A1, 2012; c) J. D. Hood, G. Noronha, (TargeGen, Inc.), US00813390B2, 2012. d) G. Noronha, C. C. Mak, J. Cao, J. Renick, A McPherson, B. Zeng,V. P. Pathak, D. L. Lohse, J. D. Hood, R. M. Soll, (TargeGen, Inc.), US 2007191405 A1, 2007.

[25] a) M. Bremerich, C. M. Conrads, T. Langletz, C. Bolm, Angew. Chem. Int. Ed. 2019, 58, 19014-19020; Angew. Chem. 2019, 131, 19190 19196; b) T. Liu, D. Zheng, Z. Li, J. Wu, Adv. Synth. Catal. 2017, 359, 2653-2659; c) N. B. Palakurthy, B. Mandal, Tetrahedron Lett. 2011, 52, $7132-7134$ 


\title{
Entry for the Table of Contents
}

\author{
$\mathrm{R}^{\text {ONS }} \mathrm{S}^{\prime \prime} \mathrm{F}$

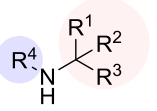 \\ HOBt $(0.02-5$ mol\%)
$\underset{\text { TMDS }(2.0 \text { equiv) }}{\stackrel{\text { DMSO or NMP }}{\text { rt }-60{ }^{\circ} \mathrm{C}}}$ \\ $\mathrm{O}_{\text {INI }} \stackrel{\mathrm{R}^{1}}{\chi^{\prime} \mathrm{R}^{2}}$ \\ $R^{-}{ }_{R^{1}} N_{R^{3}}$ \\ $1.0-125.0 \mathrm{mmol}$ \\ $>50$ examples \\ $\mathrm{R}=\mathrm{Ar}, \mathrm{Alkyl}$, and $\mathrm{ArO}$ \\ $\checkmark$ sterically hindered substrates $\checkmark$ late-stage drug functionaliztion and diversification
}

1-Hydroxybenzotriazole (HOBt) was identified as an efficient nucleophilic catalyst to activate sulfonyl fluorides and fluorosulfates. A broad-spectrum, catalytic amidation has been developed to prepare various sulfonamides and sulfamates including sterically hindered ones. In addition, the potentials of this methodology in medicinal and process chemistry have been demonstrated by the multidecagram-scale synthesis of an amantadine derivative and the synthesis of the marketed drug Fedratinib for myelofibrosis. 